Aim of the study: The McGill Quality of Life Questionnaire has been widely used for people with life-threatening illnesses since 1996. In 2016 Cohen et al. revised the McGill Quality of Life Questionnaire and improved its psychometric properties and length. The aim of the present study was to adapt the McGill Quality of Life Questionnaire - Revised (MQOL-R) into Polish. The study assessed the factorial structure, reliability, and validity of the Polish adaptation of the MQOL-R.

Material and methods: The study had a non-randomised, cross-sectional design. The Polish translation of the MQOL-R was administered to 140 people with life-threatening illnesses. Patients were recruited from acute and palliative care units. Data were analysed using confirmatory factor analysis, and correlational and multiple regression analyses.

Results: The results provide support for the measurement structure of the Polish adaptation of the MQOL-R. Both the overall scale and four subscales have satisfactory internal consistency and the construct and concurrent validity.

Conclusions: The Polish MQOL-R is psychometrically sound and may serve as a valuable asset in research on quality of life of people with life-threatening illnesses.

Key words: quality of life, palliative care, end-of-life care, life-threatening illnesses, psychometric.

Contemp Oncol (Pozn) 2018; 22 (4): 252-259 DOI: https://doi.org/10.5114/wo.2018.82645

\section{Measuring the quality of life of people with life-threatening illnesses: the internal structure of the Polish adaptation of the McGill Quality of Life Questionnaire - Revised}

\author{
Radosław Rybarski, Beata Zarzycka, Arkadiusz Bernat
}

The John Paul II Catholic University of Lublin, Lublin, Poland

\section{Introduction}

Quality of life (QOL) is defined as an "individual's perception of their position in life in the context of the culture and value systems in which they live and in relation to their goals, expectations, standards, and concerns". People with life-threatening illnesses, including those with cancer, are among those for whom the assessment of QOL is of primary importance [1].

Research on QOL of people with life-threatening illness is subject to various limitations. One of the most important ones is the background of the illness, e.g. unsatisfied needs for life, sense of physical and mental security; physical and mental disorders; and chronic pain. Therefore, in order to study the QOL of people with life-threatening illnesses, we need methods which minimise the limitations related to participation in the research.

Many QOL instruments developed for a general population or for people with specific diseases are too long for those who are in a weakened state; they contain items that are not relevant to, or inappropriate for people with life threatening illnesses, e.g. items about being as healthy as ever; or do not include domains that are important contributors to QOL of people with life-threatening illnesses, e.g. existential or spiritual domains [2]. Nonetheless, such QOL instruments continue to be used in studies of palliative care patients, e.g. the EORTC-QLQ-C30 [3], the QL-Index [4], the ESAS [5], and the SF36 [6, 7]. Several QOL instruments have been developed specifically for the end-of-life population: the EORTC-QLQ-C15-PAL and the FACIT-PAL. The latter is more comprehensive but, with 46 items, it is long.

The McGill Quality of Life Questionnaire (MQOL) was developed specifically to measure QOL of people with life-threatening illnesses. Reviews of QOL instruments for palliative care have frequently recommended MQOL over the years and, second only to the EORTC-QLQ-C30, it is the most widely used measure to assess QOL in palliative care. There has been no Polish method as of yet that would facilitate economic and multi-dimensional analysis of QOL of people with life-threatening illnesses. Therefore, we decided to adapt the McGill QOL-R.

\section{The McGill Quality of Life Questionnaire}

The MQOL, first published in 1996, was designed to measure QOL, defined as subjective well-being of people with life-threatening illnesses [8]. The MQOL contains 16 items measuring four domains: physical symptoms and general physical well-being, psychological, existential, and support. It also includes the MQOL Single-Item Scale (SIS) measuring global QOL. All MQOL items use a $0-10$ response scale with verbal anchors at each end. 
The MQOL has a time frame of two days because QOL can change rapidly in people with life-threatening illnesses, particularly those at the very end of life $[2,8]$.

The MQOL has been used in over 120 scientific articles and translated into 20 languages. The MQOL studies have demonstrated that while physical aspects of QOL are worse in those with more advanced disease, other aspects such as support and existential well-being remain positive contributors to QOL [2].

\section{The McGill Quality of Life Questionnaire - Revised}

Cohen et al. [2] improved the MQOL, addressing issues that had arisen during use of the MQOL over the years. First, they replaced Physical Symptoms and Physical Well-being subscales with the Physical subscale. Second, they reworded the item that measures control over one's life. Third, they replaced the Support subscale with the Social subscale. Finally, two items were removed from the Existential subscale, reducing it to four items [2].

The results provide evidence for the construct validity of the MQOL-R by demonstrating a well-fitting measurement structure and expected correlations between each MQOL-R subscale and the SIS. Internal consistency reliability is good for the overall scale $(\alpha=0.94)$ and acceptable $(\alpha>0.70)$ for most subscales (the Physical subscale is slightly less reliable, $\alpha=0.66$, but it combines different aspects of the physical domain that may not correlate in a consistent fashion). Nonetheless, the Physical subscale has the strongest correlation with global QOL as measured using the single item $(r=0.65)$. The other subscales were also correlated positively with global QOL at 0.43 (Psychological), 0.52 (Existential), and 0.29 (Social), and the overall MQOL-R second-order factor had a correlation of 0.67 [2].

\section{Polish adaptation of the MQOL-R}

The translation procedure of the original MQOL-R into Polish followed the principles of the International Test Commission [9]. We applied a faithful translation allowing for necessary modifications in case linguistic and cultural differences between the source and target language caused inequivalence of the tool. Three Anglicists translated the MQOL-R questions from English to Polish. Based on these translations a preliminary version of the Polish MQOL-R was compiled and sent to another English graduate who made a back translation. Using the comments provided by the translators, the Polish version of the MQOL-R was created. However, in the process of MQOL-R translation an error crept in, causing a reverse assignment of labels to points of anchor at the range of answers to question 13 . This is why we should not reverse this item in the Polish questionnaire.

\section{Material and methods}

\section{Participants}

The study had a non-randomised, cross-sectional design. Three Polish palliative care services participated in this study: The Mazovian Specialist Hospital in Radom, the Centre of Oncology in Radom, and the Centre of Oncology in Lublin. At both services patients were recruited from dedicated palliative care inpatient units. The studies were conducted in 2017. Patients at all phases of disease and treatment were judged eligible for the study if they were mentally competent and physically capable of completing the questionnaires and gave informed consent. Eligibility was determined by the patient's physician or primary nurse. During the two-month study period 150 patients completed the study. Participants having two or more missing values on the MQOL-R were excluded from further analyses. In total, six participants had to be removed. Data screening for multivariate outliers with Mahalanobis distance resulted in removal of the data from four more participants, leaving data from 140 patients in the study (76 women and 64 men). The youngest participant was 20 years old, and the oldest was 85 . The mean age in the sample was $M=61.61$ years, $S D=12.26$. Time since diagnosis ranged from 1 to 24 months, with a mean of 11.91 months $(S D=5.8)$. The average illness acceptance was assessed on a six-point scale and amounted to $(M=4.06, S D=1.11)$. Table 1 gives more detailed demographic information concerning the participants.

\section{Research tools}

\section{The McGill Quality of Life Questionnaire - Revised (see Appendix)}

The Polish translation of the MQOL-R included 14 items with a $0-10$ response scale. The instruction was to describe one's experiences over the past two days (48 hours).

\section{Single-Item Scale}

The SIS is a single-item numerical rating scale (0-10) constructed to measure overall QOL. The SIS reads "Considering all parts of my life (for example, physical, emotional, social, spiritual, and financial) over the past two days (48 hours) the quality of my life was ... very bad (0) / excellent (10).

\section{Cantril Ladder}

The Cantril Ladder is a visual analogue scale represented graphically as a ladder with steps numbered from 0 (at the bottom) to 10 (at the top). This tool serves as a subjective assessment of one's QOL. Choosing step 0 on the ladder scale means that the respondent assesses their life as the worst possible. Choosing step 10 means they perceive their life as the best possible. The instruction attached to the Cantril Ladder asked people to rate their life in one month. Thus, it was possible to seize the patient's attitude towards the future, their sense of security, hope for securing their life, and provoking a discussion about illness-related fear and insecurity.

\section{Demographics}

The survey assessed sex, age, type of primary cancer, marital status, education, place of residence, profession, time since diagnosis, and level of illness acceptance. 
Table 1. Demographic characteristics of participants

\begin{tabular}{|c|c|c|c|}
\hline Primary cancer & Frequency (\%) & Characteristic & Frequency (\%) \\
\hline Breast & $22(15.7)$ & Sex & \\
\hline Leukaemia & 19 (13.6) & Female & $76(54.3)$ \\
\hline Lymphoma & $18(12.9)$ & Male & $64(45.7)$ \\
\hline Colon & $14(10.0)$ & Education & \\
\hline Bone & $8(5.7)$ & Elementary & 19 (13.6) \\
\hline Prostate & $6(4.3)$ & Secondary & $94(67.1)$ \\
\hline Stomach & $6(4.3)$ & Higher & $27(19.3)$ \\
\hline Spleen & $5(3.6)$ & Place of residence & \\
\hline Kidney & $5(3.6)$ & Village & $35(25.0)$ \\
\hline Pancreatic & $5(3.6)$ & City/town below 200,000 & $52(37.1)$ \\
\hline Laryngeal & $4(2.9)$ & City above 200,000 & $53(37.9)$ \\
\hline Uterine & $4(2.9)$ & Profession & \\
\hline Bladder & $4(2.9)$ & Pupil/student & $4(2.9)$ \\
\hline \multirow[t]{9}{*}{ Lung } & $2(1.4)$ & Employee & $33(23.6)$ \\
\hline & & Business activity & $3(2.1)$ \\
\hline & & Pensioner & $91(65.0)$ \\
\hline & & Unemployed & $9(6.4)$ \\
\hline & & Marital status & \\
\hline & & Single & $11(7.9)$ \\
\hline & & Married & $97(69.3)$ \\
\hline & & Divorced & $8(5.7)$ \\
\hline & & Widow/widower & $24(17.1)$ \\
\hline
\end{tabular}

Total of percentages do not amount to 100 because of rounding.

\section{Procedure}

The study was planned according to the statement of Human and Animal Rights. It was approved by the local Bioethical Committee of The Catholic University of Lublin. Patients were approached at the data collector's and patient's mutual convenience. After obtaining informed consent from all participants, they were given the questionnaire battery to complete. Participants completed anonymously the Polish versions of the SIS, the MQOL-R, the Cantril Ladder, and demographic questions. The SIS was always completed first to ensure that this measure was not contaminated by completion of the MQOL-R or the Cantril Ladder. Patients had the choice of completing the questionnaire on their own or having it read aloud to them. The questionnaires were read aloud to participants by the interviewer in 98 of the cases. The entire questionnaire package was generally completed in 15-20 minutes.

\section{Statistical analysis}

The work on the Polish MQOL-R included checking the internal structure of the scale by means of the confirmatory factor analysis (CFA), and establishing its reliability and validity. Prior to data analysis, we transposed scores for MQOL-R items where necessary (items $1,3-7,10$ ), so that a score of 0 always indicated the least desirable and $10-$ the most desirable situation $[1,2]$. We applied $\alpha$ Cronbach and $\lambda_{6}$ Guttman for the assessment of the MQOL-R's reli- ability, because $\alpha$ Cronbach is not an optimum indicator of the lower level of reliability [10]. We evaluated the scale validity by examining the relationship of the MQOL-R total and subscale scores to the SIS and Cantril Ladder. The SIS asks the participants to rate their overall QOL considering all aspects of their life. This approach has been recommended by the authors of the MQOL scale [2, 8]. The Cantril Ladder assess one's predicted quality of life in one month. The study provides evidence for the convergent validity of the MQOL-R if the total score and the subscale scores have positive correlations with the SIS and Cantril Ladder. The MQOL-R subscales were created based on the results of the CFA. Regression and multiple regression techniques were used to determine the degree to which the domains of QOL predict the SIS. The CFA was conducted by means of Amos 24.0 software. The remaining analyses were performed using SPSS version 24.0.

\section{Results}

\section{Confirmatory factor analysis of the MQOL-R}

We tested the internal structure of the MQOL-R using CFA, by means of the generalised least squares method. Having completed calculations and verification of modifying indices, we introduced the covariance of measurement errors in the tested model for items $9<->14$. Item 4 (I was depressed) had a significant loading for two latent variables: Psychological (.48) and Physical (.31). This result was 


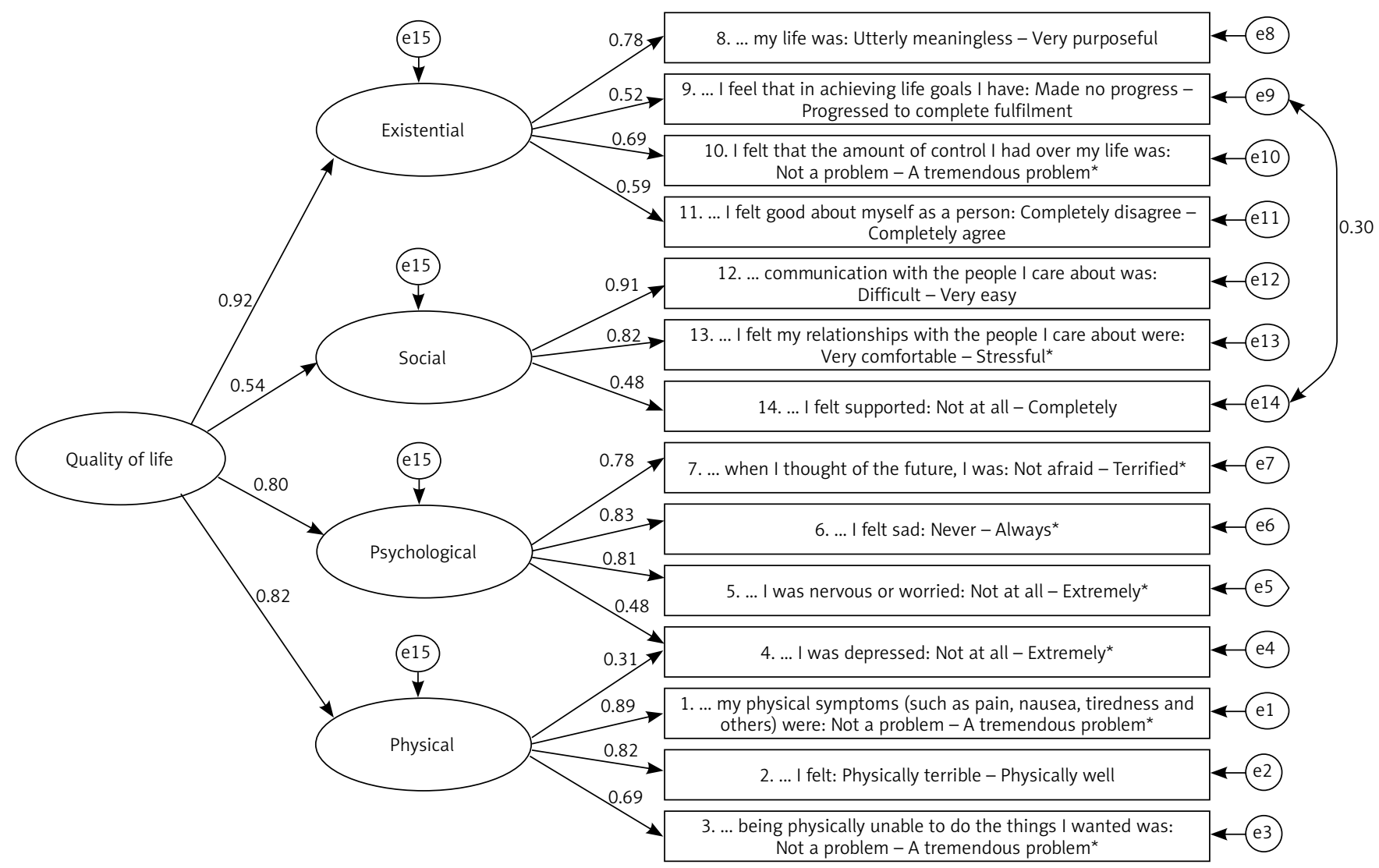

*Reverse-scored items. ... - Over the past 2 days (48 h)

Fig. 1. MQOL-R items and CFA for first-order (subscale) and second-order (overall QOL) latent factors. Factor loadings are standardised

marked with arrows on the model (Fig. 1). Table 2 shows the fit indices for this model.

An acceptable model fit was indicated by RMSEA $<0.06$ The $\chi^{2}$ test (CMIN) suggests insufficient fit, although it is clear that this statistical tool is too restrictive and often points to rejecting a model with high samples involved [11] The CMIN/df reached a satisfactory value under 5 [12]. The SRMS value was lower than 0.08 , which is acceptable. Following the strategy of presenting fit indices suggested by $\mathrm{Hu}$ and Bentler [13] if the RMSEA is 0.06 or below and the SRMR is 0.08 or below, the model fitting is good. Our model met these criteria. Factor loadings (excluding item 4) ranged from 0.52 to 0.91 . All items had high standardised factor loadings on their corresponding latent factor. The only exception was item 4 (I was depressed), which entered the MQOL-R in two latent variables. The latent factor correlations ranged from to 0.33 to 0.59 . A second-order factor model was specified (Fig. 1) to support derivation of an MQOL-R total score.

\section{Descriptive statistics of the MQOL-R subscales}

Scores for each MQOL-R item extended throughout the entire range of possible scores (0-10). Means ranged from 5.82 for the physical problems (2. I felt: physically terrible - physically well) to 8.68 for the social item (14. I felt supported). All MQOL-R items were negatively skewed, but the skewness for the majority of items was 1 or less. We decided not to transform the data for the items because trans- formation would limit the comparability to other MQOL studies [14].

The results in the MQOL-R subscales and the total result were scored by averaging across items. In order to check whether the results in subscales differ between one another, we conducted a one-way repeated-measures ANOVA. The results in the MQOL-R subscales were measured on different levels of the independent variable. The data failed to comply with the assumption of the variance sphericity (Muychaly's test: $W=0.89, p=0.002$ ); therefore, we applied the Greenhouse-Geisser correction. Thus the following result was obtained: $F(3,380)=32.51, p<0.001$, $\eta^{2}=0.19$. This means that the results in the MQOL-R sub-

Table 2. Fit indices for Confirmatory Factor Analysis of the Polish adaptation of the McGill Quality of Life Questionnaire - Revised

$\begin{array}{lc}\text { Index } & \\ \text { CMIN } & 93.35 \\ d f & 71 \\ p & 0.039 \\ \text { CMIN/df } & 1.32 \\ \text { SRMR }(<0.08) & 0.06 \\ \text { RMSEA }(<0.06) & 0.048[0.011,0.072] \\ \text { PCLOSE } & 0.539\end{array}$

SRMR - standardized root mean square residual; RMSEA - root mean square error of approximation 
Table 3. Alpha coefficients for scores on the Polish adaptation of the McGill Quality of Life Questionnaire - Revised

$\begin{array}{lccccc}\text { Coefficient } & \text { Physical } & \text { Psychological } & \text { Existential } & \text { Social } & \text { Quality of life } \\ \alpha & 0.83 & 0.89 & 0.70 & 0.79 & 0.89 \\ \lambda & 0.80 & 0.87 & 0.65 & 0.76 & 0.93\end{array}$

Table 4. Correlations of dimensions of the Polish adaptation of the McGill Quality of Life Questionnaire - Revised with Cantril Ladder

\begin{tabular}{|c|c|c|c|c|c|c|c|}
\hline & Physical & Psychological & Existential & Social & Quality of life total & SIS & Cantril \\
\hline SIS & $0.61^{\star \star \star}$ & $0.35^{\star \star \star}$ & $0.56^{\star * \star}$ & $0.34^{* * *}$ & $0.59^{* \star \star}$ & & \\
\hline Cantril & $0.50^{* * *}$ & $0.50^{* * *}$ & $0.73^{* \star *}$ & $0.35^{\star *}$ & $0.66^{\star * *}$ & $0.73^{* * *}$ & \\
\hline M & 0.17 & 6.69 & 6.95 & 8.27 & 7.04 & 5.95 & 6.00 \\
\hline SD & 2.72 & 2.68 & 2.29 & 1.82 & 1.82 & 2.39 & 2.24 \\
\hline$\alpha$ & 0.83 & 0.89 & 0.58 & 0.79 & 0.89 & & \\
\hline
\end{tabular}

SIS - single-item scale measuring overall quality of life

scales differ between one another. The multiple comparison test by Bonferroni revealed that $\mathrm{QOL}$ in the Social subscale was the highest in our sample $(M=8.26, S D=1.82$ $p<0.001$ for all comparisons), followed by Existential $(M=$ $6.97, S D=2.30)$, Psychological $(M=6.69, S D=2.68)$, and Physical $(M=6.15, S D=2.73)$. Other comparisons returned no significant differences.

\section{Reliability of the MQOL-R}

The reliability of the MQOL-R, assessed by means of the $\alpha$ Cronbach and $\lambda_{6}$ Guttman coefficients, was high for the overall scale and acceptable for all subscales (Table 3 ).

\section{Validity of the MQOL-R}

Correlations between the SIS, MQOL-R total score and subscales, and Cantril Ladder were calculated and are shown in Table 4. The Physical $(r=0.61)$ and Existential $(r=0.49)$ subscales have the strongest correlations with the SIS. Other subscales were correlated with the SIS at 0.35 (Psychological) and 0.34 (Social), and the overall MQOL-R second-order factor had a correlation of 0.59. The MQOL-R total score and the MQOL-R subscales correlated positively with the Cantril Ladder scores. Separate regression analyses were performed to determine the ability of the MQOL-R total and a combination of the MQOL-R subscales to predict the SIS. Both regression models were significant at the $p<0.001$ level. Total score predicted less of the SIS variance $\left(R_{\text {adiusted }}^{2}=0.34\right)$ than that predicted by the MQOL-R subscales $\left(R^{2}\right.$ adjusted $\left.=0.45\right)$. A combination of two subscales was significant in predicting the SIS: Physical $(\beta=0.50, t=5.47, p<0.001)$ and Existential $(\beta=0.31$, $t=3.46, p=0.001)$.

\section{Discussion}

This study assessed the internal structure, reliability, and construct validity of the Polish MQOL-R among a sample of people with cancer. The Polish MQOL-R, similarly to the original version, has four subscales: Existential, Social, Psychological, and Physical. Our results provide evidence for the construct validity of the Polish adaptation of MQOL-R by demonstrating a well-fitting measurement structure as tested using CFA. In the Polish MQOL-R item 4 (I was depressed) is problematic because it loads two latent variables: Psychological and Physical; however, as expected, it loads the variable Psychological to a greater extent. This result seems logical because feeling depressed includes both psychological and somatic symptoms. At the present development level, for calculations of the results in subscales, we suggest adding this item to the Psychological subscale, to be consistent with other MQOL studies. However, this item has been reworded to clarify that it concerns psychological aspects of feeling depressed, and its psychometric values will be examined in a future study.

Our results provide also evidence for the expected correlations between each MQOL-R subscale and the SIS. In our study, similarly to the research by Cohen et al. [2, 8, 14], all MQOL-R subscales correlated positively with the SIS. Physical and Existential subscales showed stronger correlations with SIS than Social and Psychological subscales. The regression results show that Existential and Physical subscales predict a significant amount of the SIS variance (45\%). Existential concerns as well as physical condition have been demonstrated to be of great importance to people with-life threatening illnesses. The pattern of correlations of the MQOL-R psychological, existential, social, and physical subscales with the Cantril Ladder provides further evidence that the MQOL-R subscales represent the intended domains.

In our study, like in the work by Cohen et al. $[2,8,14]$, the results in the Social and Existential subscales were higher than in the Physical subscale. This means that although QOL related to physical symptoms such as fatigue is inevitably declining in cancer patients, they can find quality in the existential, psychological, and social domains, which counterbalance the decline in the physical domain. These findings support previous observations concerning the significance of existential issues in people with life-threatening illnesses [14]. The fundamental relevance of existential concerns to the patient's experience of illness, the caregivers' important opportunity to lend support, and the need to ensure that these issues are addressed must therefore be considered integral components of competent care in oncology [2]. 


\section{Conclusions}

The Polish MQOL-R has a satisfactory reliability. Internal consistency estimates of the Psychological and Social subscales remain similar to the original MQOL-R. In the Existential subscale, $\alpha$ is slightly lower $(\alpha=0.70)$, whilst the Physical subscale $(\alpha=0.83)$ is more reliable in the Polish MQOL-R than in the original one.

A limitation of our study was the small sample, which made it impossible for us to conduct separate analyses in patients with various types of cancer and at various illness stages, which was done by the authors of the original MQOL-R [2].

The authors declare no conflict of interest.

\section{References}

1. The World Health Organization quality of life assessment (WHOQOL): Position paper from the World Health Organization. Soc Sci Med 1995; 41: 1403-1409.

2. Cohen SR, Sawatzky R, Russell LB, Shahidi J, Heyland DK, Gadermann AM. Measuring the quality of life of people at the end of life: The McGill Quality of Life Questionnaire - Revised. Palliat Med 2017; 31: 120-129.

3. Meyza J. Grupa studiująca jakość życia EORTC. In: Jakość Życia w Chorobie Nowotworowej, de Walden-Gałuszko K, Majkowicz M (eds.). Wydawnictwo Uniwersytetu Gdańskiego, Gdańsk 1994: $85-$ 88.

4. Spitzer WO, Dobson AJ, Hall J, et al. Measuring the quality of life of cancer patients: A concise QL-Index for use by physicians. J Chronic Dis 1981; 34: 585-597.

5. Majkowicz M, Czuszyńska Z, Leppert W, Maszkowska-Kopij J. Praktyczne wykorzystanie skali ESAS (Edmonton Symptom Assessment System) w opiece paliatywnej. Nowotwory 1998; 48: 847857.

6. Mchorney CA, Johne WJ, Anastasiae R. The MOS 36-Item ShortForm Health Survey (SF-36): II. Psychometric and Clinical Tests of Validity in Measuring Physical and Mental Health Constructs. Med Care 1993; 31: 247.

7. Ware JEJ. SF-36 Health Survey Update. Spine 2000; 25: 3130.

8. Cohen SR, Hassan SA, Lapointe BJ, Mount BM. Quality of life in HIV disease as measured by the McGill Quality of Life Questionnaire. AIDS 1996; 10: 1421.

9. Hambleton RK. The next generation of the ITC test translation and adaptation guidelines. Eur J Psychol Assess 2001; 17: 164-172.

10. Sijtsma K. On the use, the misuse, and the very limited usefulness of Cronbach's Alpha. Psychometrika 2009; 74: 107-120.

11. Bentler PM, Bonett DG. Significance tests and goodness of fit in the analysis of covariance structures. Psychol Bull 1980; 88: 588606.

12. Wheaton B, Muthén B, Alwin DF, Summers GF. Assessing Reliability and Stability in Panel Models. Sociol Methodol 1977; 8: 84-136.

13. Hu L, Bentler PM. Cutoff criteria for fit indexes in covariance structure analysis: Conventional criteria versus new alternatives. Struct Equ Model Multidiscip J 1999; 6: 1-55.

14. Cohen SR, Mount BM, Bruera E, Provost M, Rowe J, Tong K. Validity of the McGill Quality of Life Questionnaire in the palliative care setting: a multi-centre Canadian study demonstrating the importance of the existential domain. Palliat Med 1997; 11: 3-20.

\section{Address for correspondence}

\section{Radosław Rybarski}

The John Paul II Catholic University of Lublin 14 Radziszewskiego St. 20-950 Lublin, Poland

e-mail: radoslawrybarski@gmail.com

Submitted: 7.05.2018

Accepted: $\quad 21.07 .2018$ 


\section{Appendix}

\section{The Polish version of the the the McGill Quality of Life Questionnaire - Revised MQOL-R}

Poniższy kwestionariusz zawiera stwierdzenia, które u różnych osób mogą wyzwalać skrajne ustosunkowania. Liczby, na których zaznacza się odpowiedź, obejmują kontinuum pomiędzy dwoma skrajnymi punktami: najniższym $(0=$ w ogóle) i najwyższym (10 = ekstremalnie). Proszę zaznaczyć liczbę pomiędzy 0 a 10, która jest najbardziej zgodna z tym, co przeżywasz, czujesz. Nie ma tu dobrych i złych odpowiedzi. Całkowicie szczere odpowiedzi będą najbardziej pomocne.

\section{PRZYKŁAD}

Czuję się głodny:

\begin{tabular}{|c|l|l|l|l|l|l|l|l|l|l|l|l|}
\hline $\begin{array}{c}\text { W ogóle } \\
\text { nie }\end{array}$ & 0 & 1 & 2 & 3 & 4 & 5 & 6 & 7 & 8 & 9 & 10 & Ekstremalnie \\
\hline
\end{tabular}

- Jeżeli nie czujesz się nawet trochę głodny, powinieneś zakreślić 0.

- Jeżeli jesteś trochę głodny (właśnie skończyłeś posiłek, ale masz jeszcze miejsce na deser), powinieneś zakreślić 1, 2 albo 3.

- Jeżeli czujesz się umiarkowanie głodny (ponieważ czas positku się zbliża), powinieneś zakreślić 4, 5 albo 6.

- Jeżeli jesteś bardzo głodny (gdyż nie jadłeś cały dzień), powinieneś zakreślić 7, 8 albo 9.

- Jeżeli jesteś ekstremalnie głodny, powinieneś zakreślić 10.

\section{START}

Proszę odpowiedzieć, jak czułeś się w ciągu dwóch minionych dni.

\section{Część A. Ogólna jakość życia}

Biorąc pod uwagę wszystkie obszary mojego życia - somatyczny (cielesny), emocjonalny, społeczny, duchowy i finansowy - w ciągu ostatnich dwóch dni (48 godzin) jakość mojego życia była:

\begin{tabular}{|l|l|l|l|l|l|l|l|l|l|l|l|l|}
\hline Bardzo zła & 0 & 1 & 2 & 3 & 4 & 5 & 6 & 7 & 8 & 9 & 10 & Znakomita \\
\hline
\end{tabular}

\section{Część B. Objawy fizyczne}

1. W ciągu ostatnich dwóch dni (48 godzin) moje objawy cielesne (takie jak ból, nudności, zmęczenie i inne)*

\begin{tabular}{|c|c|c|c|c|c|c|c|c|c|c|c|c|}
\hline $\begin{array}{c}\text { Nie sprawiały mi } \\
\text { problemu }\end{array}$ & 0 & 1 & 2 & 3 & 4 & 5 & 6 & 7 & 8 & 9 & 10 & $\begin{array}{c}\text { Sprawiaty mi } \\
\text { ogromny problem }\end{array}$ \\
\hline
\end{tabular}

*Jeśli w ciągu ostatnich dwóch dni nie miałeś żadnych objawów oraz problemów cielesnych, zakreśl o - „nie sprawiaty mi problemu” i przejdź do punktu 2.

Proszę wymienić objawy cielesne, które stanowiły problem (proszę napisać wyraźnie):

2. Przez ostatnie dwa dni czułem się:

\begin{tabular}{|l|l|l|l|l|l|l|l|l|l|l|l|l|}
\hline $\begin{array}{l}\text { Fizycznie } \\
\text { okropnie }\end{array}$ & 0 & 1 & 2 & 3 & 4 & 5 & 6 & 7 & 8 & 9 & 10 & $\begin{array}{c}\text { Fizycznie } \\
\text { dobrze }\end{array}$ \\
\hline
\end{tabular}

3. W ciągu ostatnich dwóch dni (48 godzin) bycie niezdolnym fizycznie do robienia rzeczy, które chciałem robić:

\begin{tabular}{|c|c|c|c|c|c|c|c|c|c|c|c|c|}
\hline $\begin{array}{c}\text { Nie stanowito } \\
\text { problemu }\end{array}$ & 0 & 1 & 2 & 3 & 4 & 5 & 6 & 7 & 8 & 9 & 10 & $\begin{array}{c}\text { Było ogromnym } \\
\text { problemem }\end{array}$ \\
\hline
\end{tabular}

\section{Część C. Uczucia i myśli}

4. W ciągu ostatnich dwóch dni (48 godzin) odczuwałem depresję:

\begin{tabular}{|c|l|l|l|l|l|l|l|l|l|l|l|l|}
\hline W ogóle nie & 0 & 1 & 2 & 3 & 4 & 5 & 6 & 7 & 8 & 9 & 10 & Bardzo silną \\
\hline
\end{tabular}


5. W ciągu ostatnich dwóch dni (48 godzin) byłem nerwowy lub martwiłem się:

\begin{tabular}{|l|l|l|l|l|l|l|l|l|l|l|l|l|}
\hline W ogóle nie & 0 & 1 & 2 & 3 & 4 & 5 & 6 & 7 & 8 & 9 & 10 & Bardzo \\
\hline
\end{tabular}

6. W ciągu ostatnich dwóch dni (48 godzin) czułem się smutny:

\begin{tabular}{|l|l|l|l|l|l|l|l|l|l|l|l|l|}
\hline Nigdy & 0 & 1 & 2 & 3 & 4 & 5 & 6 & 7 & 8 & 9 & 10 & Cały czas \\
\hline
\end{tabular}

7. W ciągu ostatnich dwóch dni (48 godzin), gdy myślałem o przyszłości:

\begin{tabular}{|c|c|c|c|c|c|c|c|c|c|c|c|c|}
\hline $\begin{array}{c}\text { Nie obawiałem się } \\
\text { niczego }\end{array}$ & 0 & 1 & 2 & 3 & 4 & 5 & 6 & 7 & 8 & 9 & 10 & Byłem przerażony \\
\hline
\end{tabular}

8. W ciągu ostatnich dwóch dni (48 godzin) moje życie było:

\begin{tabular}{|c|c|c|c|c|c|c|c|c|c|c|c|c|}
\hline $\begin{array}{c}\text { Zupetnie pozbawione } \\
\text { sensu i celu }\end{array}$ & 0 & 1 & 2 & 3 & 4 & 5 & 6 & 7 & 8 & 9 & 10 & $\begin{array}{c}\text { Bardzo celowe } \\
\text { i sensowne }\end{array}$ \\
\hline
\end{tabular}

9. Gdy myślę o całym moim życiu, czuję, że w osiąganiu celów życiowych:

\begin{tabular}{|c|c|c|c|c|c|c|c|c|c|c|c|c|}
\hline $\begin{array}{c}\text { Nie poczynitem } \\
\text { jakichkolwiek } \\
\text { postępów }\end{array}$ & 0 & 1 & 2 & 3 & 4 & 5 & 6 & 7 & 8 & 9 & 10 & $\begin{array}{c}\text { Osiągnąłem } \\
\text { całkowite spełnienie }\end{array}$ \\
\hline
\end{tabular}

10. W ciągu ostatnich dwóch dni (48 godzin) stopień kontroli, jaką miałem nad moim życiem:

\begin{tabular}{|c|c|c|c|c|c|c|c|c|c|c|c|c|}
\hline $\begin{array}{c}\text { Nie stanowił dla } \\
\text { mnie problemu }\end{array}$ & 0 & 1 & 2 & 3 & 4 & 5 & 6 & 7 & 8 & 9 & 10 & $\begin{array}{r}\text { Był ogromnym } \\
\text { problemem }\end{array}$ \\
\hline
\end{tabular}

11. Przez ostatnie dwa dni (48 godzin) czułem się dobrze sam ze sobą:

\begin{tabular}{|c|c|c|c|c|c|c|c|c|c|c|c|c|}
\hline $\begin{array}{c}\text { Zupełnie się nie } \\
\text { zgadzam }\end{array}$ & 0 & 1 & 2 & 3 & 4 & 5 & 6 & 7 & 8 & 9 & 10 & $\begin{array}{c}\text { Całkowicie się } \\
\text { zgadzam }\end{array}$ \\
\hline
\end{tabular}

\section{Część D. Społeczna}

12. W ciągu ostatnich dwóch dni (48 godzin) porozumiewanie się z ludźmi, na których mi zależy, było:

\begin{tabular}{|l|l|l|l|l|l|l|l|l|l|l|l|l|}
\hline Trudne & 0 & 1 & 2 & 3 & 4 & 5 & 6 & 7 & 8 & 9 & 10 & Bardzo tatwe \\
\hline
\end{tabular}

13. W ciągu ostatnich dwóch dni (48 godzin) moje relacje z ludźmi, na których mi zależy, oceniam jako:

\begin{tabular}{|c|c|c|c|c|c|c|c|c|c|c|c|c|}
\hline $\begin{array}{c}\text { Zbyt chłodne, niż } \\
\text { bym tego chciał }\end{array}$ & 0 & 1 & 2 & 3 & 4 & 5 & 6 & 7 & 8 & 9 & 10 & Bardzo ciepte \\
\hline
\end{tabular}

14. W ciągu ostatnich dwóch dni (48 godzin) doświadczyłem wsparcia innych osób:

\begin{tabular}{|l|l|l|l|l|l|l|l|l|l|l|l|l|}
\hline W ogóle & 0 & 1 & 2 & 3 & 4 & 5 & 6 & 7 & 8 & 9 & 10 & Bardzo mocno \\
\hline
\end{tabular}

